\title{
Derivation of Residual
} Radioactive Material Guidelines for the Laboratory for EnergyRelated Health Research Site

\author{
T. E. Chapman
}

November 1993

Prepared for the U.S. Department of Energy San Francisco Operations Office under Contract DE-AC06-76RLO 1830

Pacific Northwest Laboratory Operated for the U.S. Department of Energy by Battelle Memorial Institute 


\title{
DISCLAIMER
}

This report was prepared as an account of work sponsored by an agency of the United States Government. Neither the United States Government nor any agency thereof, nor Battelte Memorial Institute, nor any of their employees, makes any warranty, expressed or implied, or assumes any legal liability or responsibility for the accuracy, completeness, or usefulness of any information, apparatus, product, or process disclosed, or represents that its use would not infringe privately owned rights. Reference herein to any specific commercial product, process, or service by trade name, trademark, manufacturer, or otherwise does not necessarily constitute or imply its endorsement, recommendation, or favoring by the United States Government or any agency thereof, or Battelle Memorial Institute. The views and opinions of authors expressed herein do not necessarily state or reflect those of the United States Government or any agency thereof.

\author{
PACIFIC NORTHWEST LABORATORY \\ operated by \\ BATTELLE MEMORIAL INSTITUTE \\ for the \\ UNITED STATES DEPARTMENT OF ENERGY \\ under Contract DE-ACO6-76RLO 1830
}

Printed in the United States of America

Available to DOE and DOE contractors from the

Office of Scientific and Jechnical Information, P.O. Box 62, Oak Ridge, TN 37831;

prices available from (615) 576-8401. FTS 626-8401.

Available to the public from the National Technical Information Service,

U.S. Department of Commerce, 5285 Port Royal Rd., Springfield, VA 22161. 
DERIVATION OF RESIDUAL RADIOACTIVE MATERIAL GUIDELINES FOR THE LABORATORY FOR ENERGY-RELATED HEALTH RESEARCH SITE

\section{T.E. Chapman}

November 1993

Prepared for

the U.S. Department of Energy San Francisco Operations Office under Contract DE-AC06-76RLO 1830

Pacific Northwest Laboratory Richland, Washington 99352 



\section{SUMMARY}

Residual radioactive material guidelines were derived for the Laboratory for Energy-Related Health Research (LEHR) Environmental Restoration (ER) site in Davis, California. The guideline derivation was based on a dose limit of $100 \mathrm{mrem} / \mathrm{yr}$. The U.S. Department of Energy (DOE) residual radioactive material guideline computer code was used in this evaluation. This code implements the methodology described in the DOE manual for implementing residual radioactive material guidelines. Three potential site utilization scenarios were considered with the assumption that following ER action, the site will be used without radiological restrictions. The defined scenarios vary with regard to use of the site, time spent at the site, and sources of food consumed. The results of the evaluation indicate that the basic dose limit of $100 \mathrm{mrem} / \mathrm{yr}$ will not be exceeded, provided that the soil concentrations of these radionuclides at the LEHR site do not exceed the scenario-specific values calculated by this study. Except for the extent of the contaminated zone (which is very conservative), assumptions used are as site-specific as possible, given available information. The derived guidelines are single-radionuclide guidelines and are linearly proportional to the dose limit used in the calculations. In setting the actual residual soil contamination guides for the LEHR site, DOE will apply the as low as reasonably achievable policy to the decision-making process, along with other factors such as whether a particular scenario is reasonable and appropriate, as well as using site-specific inputs to computer models based on data not yet fully determined. 


\section{ACRONYMS}

AEC

ALARA

CERCLA

DOE

ER

ERDA

LEHR

NPL

PNL

RESRAD

SARA

UC Davis
U.S. Atomic Energy Commission .

as low as reasonably achievable

Comprehensive Environmental Response, Compensation, and Liability Act of 1980 , as Amended

U.S. Department of Energy

Environmenta] Restoration

U.5. Energy Research and Development Administration

Laboratory for Energy-Related Health Research

National Priorities List

Pacific Northwest Laboratory

residual radioactive material guideline computer code

Superfund Amendments and Reauthorization Act of 1986

University of California, Davis 



\section{UNITS OF MEASURE}

\begin{tabular}{|c|c|}
\hline${ }^{\circ} \mathrm{C}$ & degrees Celsius \\
\hline of & degrees fahrenheit \\
\hline $\mathrm{cm}$ & centimeter(s) \\
\hline $\mathrm{cm}^{3}$ & cubic centimeter(s) \\
\hline d & $\operatorname{day}(s)$ \\
\hline $\mathrm{ft}$ & foot (feet) \\
\hline $\mathrm{ft}^{2}$ & square foot (feet) \\
\hline$g$ & $\operatorname{gram}(s)$ \\
\hline $\mathrm{h}$ & hour (s) \\
\hline ha & hectare(s) \\
\hline in. & inch(es) \\
\hline kg & kilogram(s) \\
\hline km & kilometer(s) \\
\hline $\mathrm{L}$ & liter (s) \\
\hline m & meter(s) \\
\hline$m^{2}$ & square meter(s) \\
\hline mi & mile(s) \\
\hline mrem & millirem(s) \\
\hline $\mathrm{pC} \mathrm{j}$ & picocurie(s) \\
\hline rem & roentgen equivalent man \\
\hline s & second $(s)$ \\
\hline$w$ & week (s) \\
\hline$y d^{2}$ & square yard(s) \\
\hline yr & year $(s)$ \\
\hline
\end{tabular}




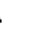




\section{CONTENTS}

SUMMARY ...........................

1.0 INTRODUCTION AND BRIEF HISTORY ................ 1

1.1 SITE DESCRIPTION AND SETTING ............. 2

1.2 SITE HISTORY . . . . . . . . . . . . . . . 5

1.3 DERIVATION OF CLEANUP GUIDELINES . . . . . . . . . . 7

2.0 LAND-USE SCENARIOS .................. 8

3.0 RESIDUAL RADIOACTIVE MATERIAL GUIDELINES . . . . . . . . . 11

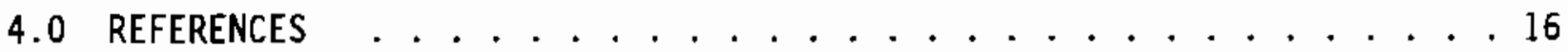

APPENDIX - PARAMETERS USED IN THE ANALYSIS OF THE LEHR SITE . . . . . . A.I 


\section{.}




\section{FIGURES}

l Location of the LEHR Site .............. 3

2 Map of the LEHR Site ................ 4

\section{IABLES}

1 Summary of Pathways for Scenarios 1, 2, and 3 at the LEHR Site . . . 9

2 Soil Residual Radioactive Material Guidelines, Scenario 1 . . . . . 11

3 Soil Residual Radioactive Material Guidelines, Scenario 2 . . . . . 13

4 Soil Residual Radioactive Material Guidelines, Scenario 3 . . . . 14

A-1 Parameters Used in the RESRAD Code for Analysis of the LEHR Site . A-1 



\subsection{INTRODUCTION AND BRIEF HISTORY}

The Laboratory for Energy-Related Health Research (LEHR) was operated by the University of California, Davis (UC Davis) for the U.S. Department of Energy (DOE). The land is owned by the Regents of the University of California and leased to the DOE; the structures at LEHR are owned by DOE (DOE 1988). A variety of operations involving the use of radioactive materials were conducted at the site between 1958 and 1989. Potential contaminated areas exist at the site from past disposal practices associated with UC Davis campus activities and with DOE-sponsored research activities at LEHR. The DOE began environmental restoration (ER) of the LEHR site in 1989 to verify that conditions, i.e., residual hazardous and radioactive materials, meet current federal guidelines. The DOE, San Francisco Operations Office has contracted with Pacific Northwest Laboratory ${ }^{(a)}$ to manage the ER of the LEHR site.

The LEHR facility is currently proposed to be on the National Priorities List (NPL) under the Comprehensive Environmental Response, Compensation, and Liability Act (CERCLA) of 1980, as amended by the Superfund Amendments and Reauthorization Act (SARA) of 1986. A preliminary assessment of the LEHR facility was completed in 1988, and the hazard ranking system process is being completed by the U.S. Environmental Protection Agency (Dames \& Moore 1993). Depending on the ranking, the ER of LEHR could be required to comply with CERCLA. DOE, at its own initiative, has undertaken a CERCLA-based remedial investigation. However, at this time, the site is not under any regulatory enforcement action.

The proposed remedial action for the site will follow the guidelines established in DOE Order 5400.5 (DOE 1990). The residual radioactive material guidel ine computer code (RESRAO) is used to derive residual radioactive material guidelines on a site-specific basis (Gilbert et al. 1989). This report presents the conservative guidelines derived to guide the ER process for the LEHR site. The derivation of these guidelines was based on the requirement that the $50-y r$ committed effective dose equivalent to a

(a) Pacific Northwest Laboratory is operated for the U.S. Department of Energy by Battelle Memorial Institute under Contract DE-AC06-76RLO 1830. 
hypothetical individual who lives or works in the immediate vicinity of the LEHR site should not exceed a dose of $100 \mathrm{mrem} / \mathrm{yr}$ following remedial action. The guidelines calculated by this study are intended to provide "worst case," i.e., conservative, values to guide the ER process. The determination of residual soit contamination criteria for the ER project should be based on site-specific geological, hydrological, and contamination data not yet fully quantified.

\subsection{SITE DESCRIPTION AND SETTING}

The LEHR site is located approximately $2.4 \mathrm{~km}(1.5 \mathrm{mi})$ south of the main UC Davis campus and the city of Davis, and approximately $1.2 \mathrm{~km}(0.75 \mathrm{mi})$ south of Interstate 80 on County Road 79 (Figure 1). The LEHR site covers approximately 6.1 ha (15 acres) and contains several buildings, including a main administration and office building, two animal hospitals, laboratory and support buildings, waste-handling facilities, and numerous outside dog pens (Figure 2).

Also located on the LEHR site are two cells of an inactive UC Davis landfill, a UC Davis low-level radioactive waste disposal site, and a DOE lowlevel radioactive waste disposal site.

The LEHR site is located in a rural area and is bounded on all sides by UC Davis property. The southern border of the LEHR facility is the northern levee on the South Fork of Putah Creek. Private land surrounds the UC Davis property on all sides. Land use in the vicinity of UC Davis and the LEHR facility is predominantly agricultural. Approximately $60 \%$ of Solano County's total area is farmland and $18 \%$ is irrigated cropland (U.S. Bureau of Census 1989). The current population of Davis is approximately 46,000 , and the current population of Solano County is about 340,400 (U.S. Bureau of the Census 1991).

Surface soil at the LEHR facility is classified in the Reiff series as a fine sandy loam. The dominant texture of the upper subsoil is sandy, and the dominant texture of the lower subsoil is gravelly, loamy (silty) sand. The soil is characterized by a deep, permeable profile and good drainage (Dames \& Moore 1993). 


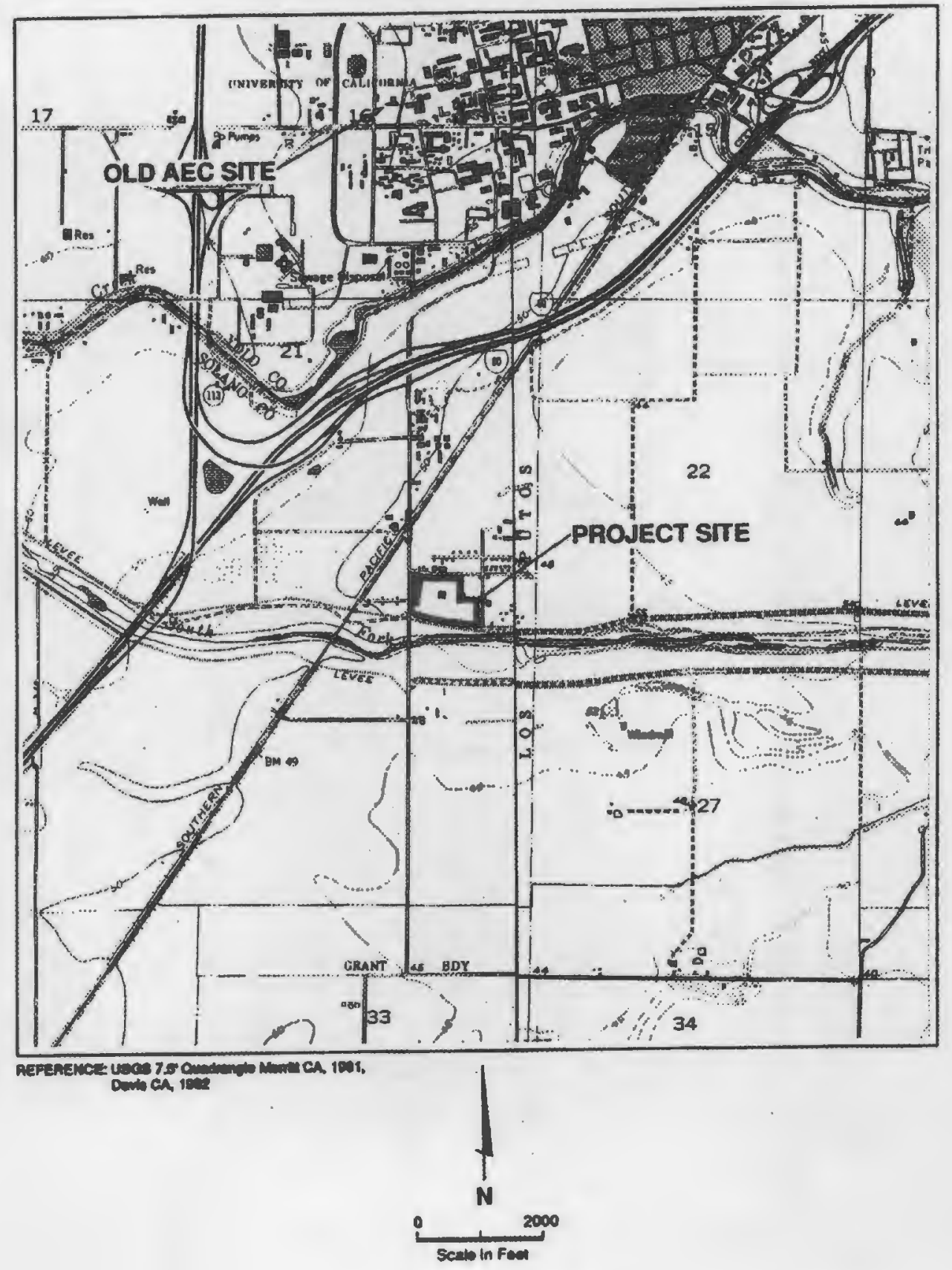

FIGURE 1. Location of the LEHR Site 


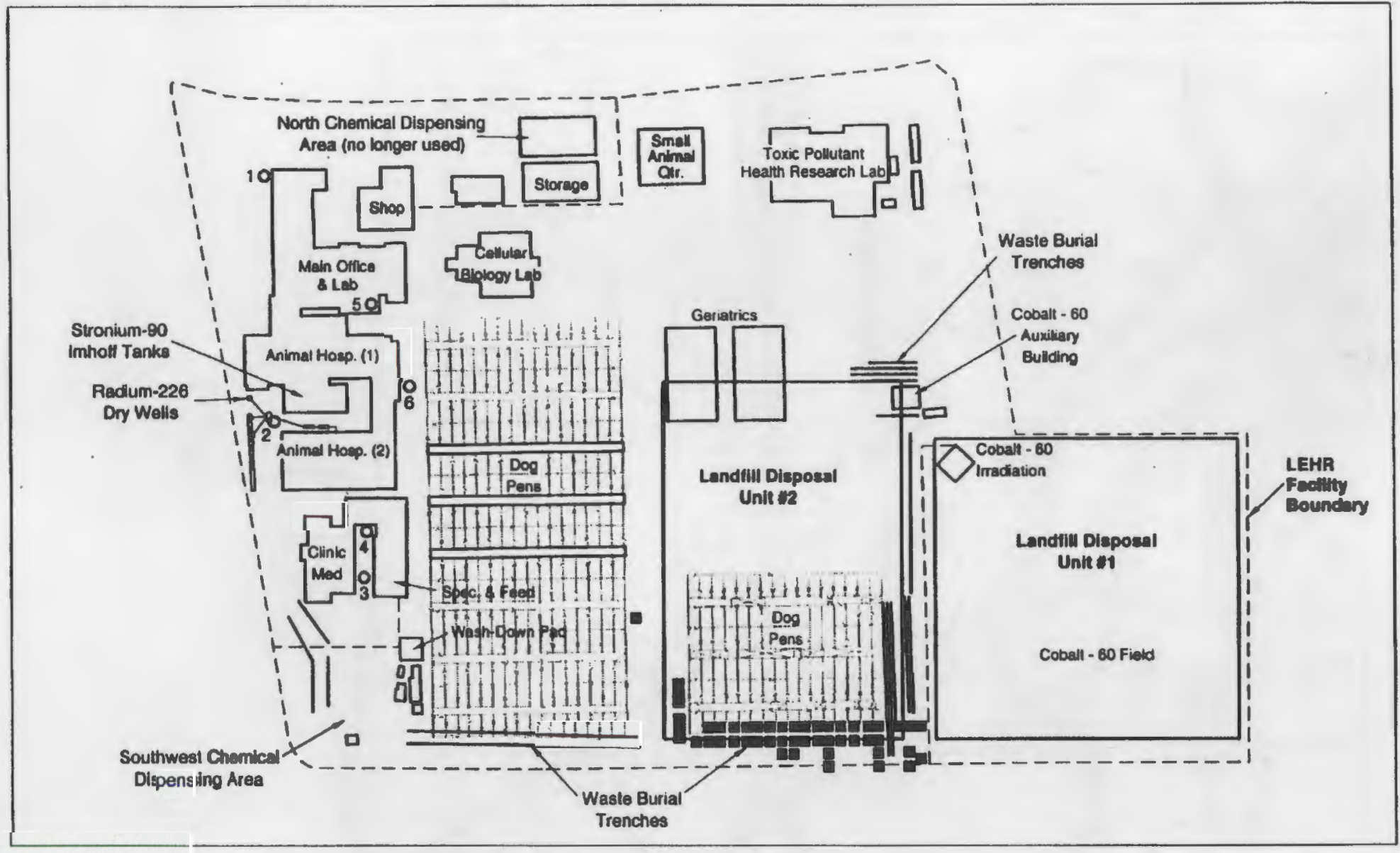

EXPLANATION

- Radioactive Trenches and Holes

- Waste Burial Trenches

- Domestic Septic Tanks

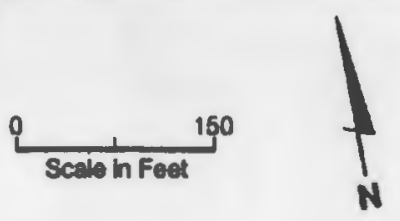

FIGURE 2. Map of the LEHR Site 
Groundwater beneath the site ranges in depth from approximately 13.7 to $21.3 \mathrm{~m}$ ( 45 to $70 \mathrm{ft}$ ) below ground surface and has been divided into two zones (Dames \& Moore 1993). The first hydrostratigraphic unit consists of finegrained sediment varying from very fine-grained sandy silt to sandy clay. The second hydrostratigraphic unit consists of coarse sand and cobble gravel. Because of the agricultural use of nearby land, many domestic and supply wells are located close to the LEHR facility; however, no active groundwater wells are present on the LEHR site. The climate in the region of the LEHR facility is temperate with mild winters and long summers. The average temperature is $8.3^{\circ} \mathrm{C}\left(46.9^{\circ} \mathrm{F}\right)$ in winter and $23^{\circ} \mathrm{C}\left(73^{\circ} \mathrm{F}\right)$ in summer (National Oceanic and Atmospheric Administration 1985; DOE 1988). The mean annual precipitation at the Davis Meteorological Station is $43 \mathrm{~cm}(17.0 \mathrm{in.})$, most of which occurs between October and April (National Climatic Data Centers 1992). From the winter of 1986-1987 unti1 the winter of 1992-1993, most of California, including the Davis area, experienced drought conditions. Regionally, the drought resulted in decreased aquifer recharge thus groundwater levels have decreased due to the effects of drought and pumping for agricultural, municipal, and industrial uses.

\subsection{SITE HISTORY}

Fu11-scale experimental use of radioactive materials began at LEHR in 1960. In the initial stages of operation at the LEHR facility, waste was handled through a central waste-handling facility on the main campus. However, because of safety concerns, waste handling for LEHR-generated waste was returned to the LEHR facility in the early 1960s.

Portions of the LEHR site were previously used as the UC Davis campus landfil1, which consisted of three separate disposal units (two of which are located on the LEHR site). Disposal in the oldest unit (Inactive Disposal Unit No. 1) began in the 1940 s and ceased in either the late 1950s or early 1960s. The area is now covered by the Cobalt-60 Irradiator field at the LEHR facility (Figure 2). The next oldest disposal area (Inactive Disposal Unit No. 2) received wastes from 1956 to 1967 . This disposal area is partially covered with the eastern-most sections of two sets of dog pens used to house the beagles (used for animal research) at the LEHR facility. A third landfill 
disposal unit, located about $180 \mathrm{~m}(600 \mathrm{ft})$ east of LEHR (1nactive Disposal Unit No. 3), was used from 1963 to 1967.

Laboratory research continued through sponsorship of the U.S. Energy Research and Development Administration (ERDA) (predecessor to DDE) and DOE until funding for the DOE-related work was terminated in fiscal year 1989 (except for limited data evaluation). During the 30-year operation of the LEHR facility, various wastes were generated and disposed of on-site. These wastes included radioactive, biological, chemical, municipal, and laboratory debris.

In 1987, a DDE team conducted an environmental survey of the facility to identify environmental problems and risks associated with LEHR. This survey concluded that several potential environmental threats existed at the LEHR facility. Waste burial sites, the Imhoff treatment tanks, septic system, and associated leach fields (Strontium-90 Leach Fields) were considered to be potential sources of chemical and radioactive leachate to groundwater. Additionally, dog pen and cobalt-60 irradiation activities were considered to be potential sources of soil contamination (DOE 1988).

During 1987 and 1988, Wahler Associates conducted groundwater and soils investigations at LEHR (the Phase I study) to evaluate chemical radioactive contamination in the soils and groundwater at the site. The purpose of this study was to provide a basis for subsequent investigations and monitoring at the site (Wahler Associates 1988, 1989).

In early 1990, Dames Moore began the Phase II Site Characterization study. The results of this survey indicated the presence of residual radioactive contamination, primarily radium-226 and strontium-90, in on-site soil (Dames \& Moore 1993). A maximum concentration of $19 \mathrm{pCi} / \mathrm{g}$ of strontium90 was detected in one sample from the northern part of LEHR; maximum concentrations of $0.61,0.70,0.22$, and $0.10 \mathrm{pCi} / \mathrm{g}$ of strontium-90 were detected in the radium-226 seepage pits, southwest chemical dispensing area, dog pen areas, and north chemical dispensing area, respectively. No strontium-90 was reported in samples analyzed from the strontium-90 leach field. Average background soil concentrations of strontium-90 ranged from nondetectable $(<0.05 \mathrm{pCi} / \mathrm{g})$ to $0.24 \mathrm{pC} i / 9$. Cesium-137 was detected in the 
radium-226 seepage pits, dog pen area, and strontium-90 leach field area. The cesium-137 concentrations in these three areas were at or below the maximum measured background concentration of $0.2 \mathrm{pCi} / \mathrm{g}$.

Average background soil concentrations of radium-226 ranged from 0.05 $\mathrm{pC} \mathrm{C} / \mathrm{g}$ to $1.4 \mathrm{pCi} / \mathrm{g}$. Maximum reported activities (including contributions from background) of radium-226 of $1.31 \mathrm{pCi} / \mathrm{g}$ in North Chemical Dispensing area, $0.75 \mathrm{pCi} / \mathrm{g}$ in the Strontium-90 Leach Fields, $1.35 \mathrm{pCi} / \mathrm{g}$ in the Radium-226 Dry We11 Area, $0.9 \mathrm{pCi} / \mathrm{g}$ in the Southwest Chemical Dispensing Area, $1.4 \mathrm{pCi} / \mathrm{g}$ in the Dog Pen Area. Radium-226 daughter products were also detected in soil samples from several areas of the LEHR site.

\subsection{DERIVATION OF CLEANUP GUIDELINES}

Most DOE cleanup guidelines applicable to remedial actions are generic in nature, including the guideline for radium-226 in soil; however, guidelines for strontium-90 and cesium-137 in soil are derived on a site-specific basis (DOE 1990, 1992). The purpose of this report is to present the residual radioactive material guidelines applicable to guide remedial action at the LEHR site, i.e., the residual concentrations of 1ong-1ived radioactive materials in a homogeneously contaminated area that must not be exceeded if the site is to be released for use without radiological restrictions. The derivation of site-specific, single-radionuclide guidelines for the LEHR site is based on a dose limit of $100 \mathrm{mrem} / \mathrm{yr}$ to a member of the public (DOE 1990, 1992) and the assumption that a single radionuclide is the only radionuclide present at an above-background concentration. The RESRAD computer code, which implements the methodology described in the DOE manual for implementing residual radioactive material guidelines (Gilbert et al, 1989), was used to derive these guidelines. The guidelines are intended to guide remediation only, and actual site-specific, residual radioactive material soil guidelines should be determined by DOE using more appropriate site-specific data, when available, taking into account other sociological, economical, and political factors. 


\subsection{LAND-USE SCENARIOS}

Three potential plausible exposure scenarios are considered for the LEHR site. All scenarios assume that, at some time following remediation, the site will be released for use without radiological restrictions.

Scenario 1 assumes research use of the site (ANL 1993). Under this scenario, a hypothetical individual is assumed to work in the area of the site for $8 \mathrm{~h} / \mathrm{d}(6 \mathrm{~h}$ outdoors and $2 \mathrm{~h}$ indoors), $5 \mathrm{~d} / \mathrm{w}, 50 \mathrm{w} / \mathrm{yr}$. Therefore, in $1 \mathrm{yr}$, the research worker is assumed to spend $17 \%$ of the time working outdoors at the site, $6 \%$ of the time working indoors at the site, and $77 \%$ of the time away from the site. It is assumed that the worker does not ingest water, plant foods, or fish obtained from the remediated area, or meat or milk from livestock rajsed in the remediated area.

Scenario 2 assumes recreational use of the site. Under this scenario, it is assumed that, at some time in the future, the whole site is transformed into a public recreational park and a hypothetical individual spends $15 \mathrm{~h} / \mathrm{w}$, $50 \mathrm{w} / \mathrm{yr}$, in the remediated area of the park. Therefore, in $1 \mathrm{yr}$, this generic recreationist is assumed to spend $9 \%$ of the time in the remediated area and $91 \%$ of the time away from the site. It is assumed that the recreationist does ingest water obtained from the remediated area, but does not ingest plant foods, meat, or milk from livestock raised in the remediated area. Also, it is assumed that a portion of any fish or other aquatic food consumed by the recreationist is obtained from the site. This scenario assumes that drinking water supplies for the park area, if any, are from an onsite source, i.e., a wel1. Additionally, this scenario assumes that fishing is allowed in the Putah Creek nature area.

Scenario 3 assumes agricultural use of the site (ANL 1993). Under this scenario, it is assumed that at some time in the future, the whole site is transformed into a farm and, in $1 \mathrm{yr}$, a hypothetical resident farmer spends $50 \%$ of the time indoors in the remediated area, $25 \%$ of the time outdoors in the remediated area, and $25 \%$ of the time away from the site. The resident farmer is assumed to ingest plant foods grown in the garden and fish and other aquatic food obtained from the site. This individual is also assumed to 
ingest meat and milk obtained from livestock raised in the remediated area. The resident's drinking water supply is assumed to be from an on-site well. Potential radiation doses resulting from eight exposure pathways are analyzed as follows:

- direct exposure to external gamma radiation from the decontaminated soil material

- internal radiation from inhalation of contaminated dust including radon and its progeny when applicable

- internal radiation from ingestion of plant foods grown in the remediated area and irrigated with water from local groundwater wells

- internal radiation from ingestion of meat obtained from livestock fed with fodder grown in the remediated area and with water drawn from inside the area

- internal radiation from ingestion of milk obtained from livestock fed with fodder grown in the remediated area and with water drawn from inside the area

- internal radiation from ingestion of water drawn from inside the area

- internal radiation from ingestion of fish and other aquatic food obtained from the site

- internal radiation from ingestion of on-site soit.

All pathways considered for scenarios 1,2 , and 3 are summarized in Table 1 .

IABLE 1. Summary of Pathways for Scenarios 1, 2, and 3 at the LEHR Site

Pathway

External Gamma Exposure

Inhalation of dust

Ingestion of P1ant Foods

Ingestion of Meat

Ingestion of Milk

Ingestion of Fish

Ingestion of Soil

Ingestion of Water
Scenario 1
(Researcher)

Yes

Yes

No

No

No

No

Yes

No
Scenario 2 (Recreationist)
Scenario 3 (Resident Farmer) 
Using the RESRAD computer code (Gilbert et al. 1989) to calculate potential radiation doses to the hypothetical future researcher, recreationist, or resident farmer, the following assumptions were made for these scenarios:

- During $1 \mathrm{yr}$, the researcher spends $1500 \mathrm{~h}(17 \%)$ outdoors at the site, $500 \mathrm{~h}(6 \%)$ indoors at the site, and $6760 \mathrm{~h}(77 \%)$ away from the remediated area; the recreationist spends $750 \mathrm{~h} / \mathrm{yr}(9 \%)$ onsite; and the resident farmer spends $4380 \mathrm{~h} \mathrm{(50 \% )}$ indoors, $2190 \mathrm{~h}$ (25\%) outdoors in the remediated area, and $2190 \mathrm{~h}(25 \%)$ away from the site.

- The walls, floors, and foundation of the house or office building reduce external exposure by $30 \%$.

- The indoor dust level in the house or office building is $40 \%$ of the outdoor dust level (Gilbert et a]. 1989).

- $50 \%$ of the plant food diet consumed by the resident farmer is grown in a garden in the remediated area. Neither the researcher nor the recreationist consumes these plant foods.

- The size of the remediated area is sufficient to grow all of the forage needed for raising livestock in the remediated area to produce sufficient meat and milk for the resident farmer. Neither the researcher nor the recreationist consumes this meat or milk.

- $50 \%$ of the fish and other aquatic food consumed by the farmer is obtained from the site and $5 \%$ for the recreationist. The researcher does not consume aquatic food obtained from the site.

- After remedial action, no cover material is placed over the remediated area.

- The thickness of the contaminated zone is a very conservative average value derived from Dames \& Moore (1993) measurements. The whole area of the $\operatorname{LEHR}$ site $\left(60,700 \mathrm{~m}^{2}\left[653,400 \mathrm{ft}^{2}\right]\right)$ is conservatively assumed to be homogeneously contaminated to a thickness of $9.1 \mathrm{~m}(30 \mathrm{ft})$.

The input parameters for the RESRAD computer program are listed in the Appendix. 


\subsection{RESIDUAL RADIOACTIVE MATERIAL GUIDELINES}

The residual radioactive material guideline is the concentration of residual radioactive material that can remain in a remediated area and still allow use of the area without radiological restrictions. On the basis of the DOE annual radiation dose 1 imit of $100 \mathrm{mrem} / \mathrm{yr}$ for an individual member of the public (DOE 1990, 1992), the single-radionuclide residual, radioactive material guideline, $G_{i}$, for the LEHR site can be calculated as

$$
G_{i}=100 / D S R_{i},
$$

where $D R_{\mathfrak{i}}$ is the total dose/source concentration ratio. The calculated residual radioactive material guidelines for radionuclides at the LEHR site are presented in Tables 2, 3, and 4. The derived guidelines are linearly proportional to the dose limit used in the calculation. The radionuclides listed in Tables 2, 3, and 4 are those that the RESRAD computer code is capable of calculating. Therefore, the presence of a radionuclide in Table 2, 3 , or 4 does not indicate that it is potentially present on the LEHR site.

When implementing the derived radionuclide guidelines for decontamination of a site, the sum-of-fractions rule applies. That is, the

TABLE 2. Soil Residual Radioactive Material Guidelines, Scenario 1

\section{Radioisotope}

Ac-227

Am-241

Am-243

C-14

Ca-41

Ce-144

C) -36

$\mathrm{Cm}-243$

Cm-244

Co-60

Co-57

Cs -134

Cs -135

Cs -137
Residual Radioactive Material Guidel ine $(\mathrm{pCi} / \mathrm{g})$

$3.5 \mathrm{E}+0 \mathrm{I}$

4. $7 \mathrm{E}+02$

2. $2 \mathrm{E}+02$

$6.4 \mathrm{E}+06$

$1.0 E+07$

$1.4 \mathrm{E}+03$

$3.9 E+05$

$3.4 E+02$

9.7 $\mathrm{E}+02$

2.0E+01

$9.0 \mathrm{E}+02$

4. $2 \mathrm{E}+01$

1. $9 \mathrm{E}+06$

9. $1 E+01^{(a)}$ 
IABLE 2. (contd)

\section{Radioisotope}

Eu-152

Eu-154

Eu- 155

$\mathrm{Fe}-55$

Gd -152

$\mathrm{H}-3$

I -129

K-40

$\mathrm{Mn}-54$

$\mathrm{Na}-22$

$\mathrm{Nb}-94$

$\mathrm{Ni}-63$

$\mathrm{Ni}-59$

$\mathrm{Np}-237$

$\mathrm{Pa}-231$

$\mathrm{Pb}-210$

$\mathrm{Pu}-240$

$\mathrm{Pu}-241$

$\mathrm{Pu}-242$

$\mathrm{Pu}-238$

Pu-239

$\mathrm{Ra}-226$

$\mathrm{Ra}-228$

$\mathrm{Ru}-106$

$\mathrm{Sb}-125$

Sm-151

$\mathrm{Sr}-90$

Tc -99

Th- 230

Th-232

Th-228

Th- 229

$\mathrm{U}-232$

$\mathrm{U}-233$

$\mathrm{U}-234$

$\mathrm{U}-235$

$\mathrm{U}-236$

$\mathrm{U}-238$
Residual Radioactive Material Guideline $(\mathrm{pCi} / \mathrm{q})$

4. $6 E+01$

4. $1 E+01$

2.7E+03

$1.6 \mathrm{E}+07$

1. $2 \mathrm{E}+03$

2.1E+08

1. $1 \mathrm{E}+04$

3. $8 \mathrm{E}+02$

$7.7 \mathrm{E}+01$

2. $9 E+01$

3. $2 \mathrm{E}+0 \mathrm{l}$

1. $7 \mathrm{E}+07$

2. $8 \mathrm{E}+07$

$1.8 \mathrm{E}+02$

$3.0 \mathrm{E}+01$

$1.8 \mathrm{E}+03$

5.1E+02

1. $5 \mathrm{E}+04$

$5.4 E+02$

$5.7 E+02$

$5.1 \mathrm{E}+02$

$2.6 \mathrm{E}+01$

$3.4 \mathrm{E}+01$

3. $3 \mathrm{E}+02$

1. $6 \mathrm{E}+02$

8. $4 \mathrm{E}+06$

$7.1 \mathrm{E}+04^{(\mathrm{a})}$

8. $3 E+06$

3. $3 \mathrm{E}+01$

$1.8 \mathrm{E}+01$

3. $2 \mathrm{E}+01$

$8.6 \mathrm{E}+01$

3. $3 E+01$

7.2E+01

8. $3 \mathrm{E}+01$

3. $5 \mathrm{E}+02$

2. $4 \mathrm{E}+03$

1. $4 \mathrm{E}+03$

(a) Taken from Table 4, ANL 1993. 
TABLE 3. Soil Residual Radioactive Material Guidelines, Scenario 2

\section{Radioi sotope}

$\mathrm{Ac}-227$

Am-241

Am-243

C- 14

Ca-41

Ce -144

C1 -36

$\mathrm{Cm}-243$

$\mathrm{Cm}-244$

$\mathrm{Co}-57$

Co-60

Cs-134

Cs-135

Cs -137

Eu-152

Eu-154

Eu-155

$\mathrm{Fe}-55$

Gd-152

$\mathrm{H}-3$

I -129

K- 40

$\mathrm{Mn}-54$

$\mathrm{Na}-22$

$\mathrm{Nb}-94$

$\mathrm{Ni}-59$

$\mathrm{Ni}-63$

$\mathrm{Np}-237$

$\mathrm{Pa}-231$

$\mathrm{Pb}-210$

$\mathrm{Pu}-238$

Pu-239

$\mathrm{Pu}-240$

Pu-241

$\mathrm{Pu}-242$

Ra-226

Ra-228

$\mathrm{Ru}-106$

Sb- 125

Sm-151

Sr -90

Tc- 99

Th-228

Th-229

Th-230

Th-232
Residual Radioactive

Material Guideline (pCi/g)

\section{8. $0 \mathrm{E}+01$}

1. $0 \mathrm{E}+03$

1. $5 \mathrm{E}+01$

$9.1 \mathrm{E}+01$

$3.7 \mathrm{E}+06$

$3.5 \mathrm{E}+03$

3. $5 \mathrm{E}+03$

$3.2 \mathrm{E}+00$

$5.4 \mathrm{E}+00$

2. $2 \mathrm{E}+03$

4. $9 \mathrm{E}+01$

1. $0 \mathrm{E}+02$

4. 3E+06

2. $2 \mathrm{E}+02$

$1,1 \mathrm{E}+02$

1. $0 \mathrm{E}+02$

6. $7 \mathrm{E}+03$

$3.8 \mathrm{E}+07$

$3.8 \mathrm{E}+01$

$6.5 \mathrm{E}+06$

2.7E+02

$1.6 \mathrm{E}+02$

1. $8 \mathrm{E}+02$

7. $2 \mathrm{E}+01$

7. $3 \mathrm{E}+00$

$6.6 \mathrm{E}+07$

3. $8 \mathrm{E}+07$

$3.5 \mathrm{E}+00$

4. $3 \mathrm{E}+01$

4. $0 \mathrm{E}+03$

1. $2 \mathrm{E}+03$

1. $1 \mathrm{E}+03$

1. $1 \mathrm{E}+03$

3. $6 \mathrm{E}+04$

1. $1 \mathrm{E}+03$

7. $1 \mathrm{E}+0 \mathrm{l}$

8. $4 \mathrm{E}+01$

8. $2 \mathrm{E}+02$

3. $9 \mathrm{E}+02$

2. $0 \mathrm{E}+04$

1. $6 \mathrm{E}+05$

3. $8 \mathrm{E}+04$

7. $9 \mathrm{E}+01$

2. $0 \mathrm{E}+02$

9. $0 \mathrm{E}+01$

$4.4 \mathrm{E}+01$ 
TABLE 3. (contd)

\section{Radiojsotope}

$\mathrm{U}-232$

$\mathrm{U}-233$

$\mathrm{U}-234$

$\mathrm{U}-235$

$\mathrm{U}-236$

$\mathrm{U}-238$
Residual Radioactive Material Guideline $(\mathrm{pCi} / \mathrm{q})$
8. $1 E+01$
1. $6 \mathrm{E}+03$
2. $0 \mathrm{E}+03$
2. $1 \mathrm{E}+02$
5. $5 \mathrm{E}+03$
3. $4 \mathrm{E}+03$

TABLE 4. Soil Residual Radioactive Material Guidelines, Scenario 3

\section{Radioisotope}

Ac- -227

Am-241

Am-243

C -14

$\mathrm{Ca}-41$

Ce -144

C1 $1-36$

$\mathrm{Cm}-243$

$\mathrm{Cm}-244$

Co-60

$\mathrm{Co}-57$

Cs -134

Cs-135

Cs -137

Eu-152

Eu-154

Eu-155

$\mathrm{Fe}-55$

Gd-152

H-3

I -129

K-40

$\mathrm{Mn}-54$

$\mathrm{Na}-22$

Nb-94

$\mathrm{Ni}-63$

$\mathrm{Ni}-59$

$\mathrm{Np}-237$

$\mathrm{Pa}-231$
Residual Radioactive

Material Guideline (pCi/g)

9. $0 \mathrm{E}+00$

$1.6 \mathrm{E}+02$

1. $1 \mathrm{E}+01$

9. $0 \mathrm{E}+00$

1. $4 \mathrm{E}+04$

5. $0 E+01$

8. $9 \mathrm{E}+00$

2.3E-0l

3. $8 \mathrm{E}-01$

7. $0 \mathrm{E}+00$

3. $1 E+01$

1. $4 \mathrm{E}+01$

2. $8 \mathrm{E}+03$

3. $2 E+01^{(a)}$

$1.6 \mathrm{E}+01$

1. $4 \mathrm{E}+01$

9. $6 \mathrm{E}+02$

1. $7 \mathrm{E}+06$

2.7E+00

$6.8 \mathrm{E}+04$

3. $8 \mathrm{E}+00$

1. $5 \mathrm{E}+01$

2. $7 \mathrm{E}+01$

1. $0 \mathrm{E}+01$

7. $4 \mathrm{E}-01$

8. $9 \mathrm{E}+04$

2. $3 \mathrm{E}+05$

$1.8 \mathrm{E}-01$

3. $0 \mathrm{E}+00$ 
IABLE 4. (contd)

\begin{tabular}{lc} 
Radioisotope & $\begin{array}{c}\text { Residual Radioactive } \\
\text { Materia] Guideline } \\
(\mathrm{pC} / \mathrm{g})\end{array}$ \\
\hline $\mathrm{Pb}-210$ & $2.4 \mathrm{E}+00$ \\
$\mathrm{Pu}-240$ & $1.7 \mathrm{E}+02$ \\
$\mathrm{Pu}-241$ & $5.3 \mathrm{E}+03$ \\
$\mathrm{Pu}-242$ & $1.8 \mathrm{E}+02$ \\
$\mathrm{Pu}-238$ & $1.9 \mathrm{E}+02$ \\
$\mathrm{Pu}-239$ & $1.7 \mathrm{E}+02$ \\
$\mathrm{Ra}-226$ & $1.9 \mathrm{E}+00$ \\
$\mathrm{Ra}-228$ & $1.1 \mathrm{E}+01$ \\
$\mathrm{Ru}-106$ & $1.1 \mathrm{E}+02$ \\
$\mathrm{Sb}-125$ & $5.6 \mathrm{E}+01$ \\
$\mathrm{Sm}-151$ & $1.4 \mathrm{E}+03$ \\
$\mathrm{Sr}-90$ & $3.7 \mathrm{E}+01(\mathrm{a})$ \\
$\mathrm{TC}-99$ & $5.5 \mathrm{E}+02$ \\
$\mathrm{Th}-230$ & $2.4 \mathrm{E}+00$ \\
$\mathrm{Th}-232$ & $5.9 \mathrm{E}+00$ \\
$\mathrm{Th}-228$ & $1.0 \mathrm{E}+01$ \\
$\mathrm{Th}-229$ & $2.0 \mathrm{E}+01$ \\
$\mathrm{U}-232$ & $1.1 \mathrm{E}+01$ \\
$\mathrm{U}-233$ & $1.7 \mathrm{E}+02$ \\
$\mathrm{U}-234$ & $6.1 \mathrm{E}+01$ \\
$\mathrm{U}-235$ & $1.5 \mathrm{E}+01$ \\
$\mathrm{U}-236$ & $6.1 \mathrm{E}+01$ \\
$\mathrm{U}-238$ & $4.1 \mathrm{E}+02$ \\
\end{tabular}

(a) Taken from Table 4, ANL. 1993.

summation of the fractions of radionuclide concentrations, $S_{i}$, remaining onsite, averaged over an area of $100 \mathrm{~m}^{2}\left(120 \mathrm{yd}^{2}\right)$ and a depth of $15 \mathrm{~cm}(6 \mathrm{in}$. and divided by their guidelines, $G_{\mathfrak{i}}$, should not be greater than unity, or

$$
\sum_{\mathfrak{i}} S_{\mathfrak{i}} / G_{\mathfrak{i}} \leq 1 .
$$

The derived residual radioactive material guidelines for the LEHR site are single-radionuclide guidelines for a large, homogeneously contaminated area. For smaller isolated areas of contamination, the allowable concentration that can remain on-site may be higher than the homogeneous guideline, depending on the size of the area of contamination. 
In setting the actual radionuclide guidelines for the LEHR site, DOE will apply the as low as reasonably achievable (ALARA) policy to the decisionmaking process, along with other factors, such as whether a particular scenario is reasonable and appropriate. Additionally, soil guides should be revised to account for actual site-specific hydrology, geology, and other physical factors determined during the site remedial investigation. The guidelines presented in this study should be applied only by health physicists or other persons experienced in performing health physics computer modeling for the environment.

\subsection{REFERENCES}

ANL. 1993. Derivation of Strontium-90 and Cesium-137 Residual Radioactive Material Guidelines for the Laboratory for Energy-Related Health Research, University of California, Davis. ANL/EAIS/TM-74, April 1993. Argonne National Laboratory, Argonne, Illinois.

Dames \& Moore. 1993. Phase II Site Characterization Report for the LEHR Environmental Restoration, University of California at Davis. Volumes I, II, and III. Dames \& Moore, Sacramento, California.

Gilbert, T.L., et a1. 1989. A Manual for Implementing Residual Radioactive Material Guidelines. ANL/ES-160 (DOE/CH/8901), Argonne National Laboratory, Argonne, Illinois.

National Oceanic and Atmospheric Administration. 1985. Local Climatological Data 1985, Sacramento, California. National Climatic Data Centers, Asheville, North Carolina.

National Climatic Data Centers. 1992. National Oceanic and Atmospheric Administration Database. Information obtained through the University of Nevada Desert Research Institute, Western Regional C1imate Data Center (Davis 2 WSW station).

Rockwel1 Internationa]. 1984. Initial Assessment Survey of the DOE LEHR Site of University of California-Davis. AI-DOE-13504, Rockwell International, San Francisco, California.

U.S. Bureau of the Census. 1989. 1987 Census of Agriculture. Volume 1, Part 5, U.S. Department of Commerce, Washington, D.C.

U.S. Bureau of the Census. 1991. Summary of Population and Housing Characteristics. CHP 1-6, U.S. Department of Commerce, Washington, D.C.

U.S. Department of Energy (DOE). 1988. Environmental Survey Preliminary Report Laboratory for Energy-Related Health Research, Davis, California. 
DOE/EH/OEV-28-P, Office of Environmental Audit of the Office of Environment, Safety and Health, U.S. Department of Energy, Washington, D.C.

U.S. Department of Energy (DOE). 1990. "Radiation Protection of the Public and Environment." DOE Order 5400.5.

U.S. Department of Energy (DOE). 1992. Radiological Control Manual. Washington, D.C.

Wahler Associates. 1988. Groundwater and Soils Investigation, U.C. Davis Research Facility, Davis, California. Prepared by Wahler Associates for University of California, Davis, California.

Wahler Associates. 1989. Groundwater and Soils Investigation, U.C. Davis LEHR Facility, Davis California. Volumes I and II, prepared by Wahler Associates for University of California, Davis, California. 

APPENDIX

PARAMETERS USED IN THE ANALYSIS OF THE LEHR SITE 
APPENDIX

\section{PARAMETERS USED IN THE ANALYSIS OF THE LEHR SITE}

The parametric values used in the RESRAD code for the analysis of the LEHR site are listed in Table A.1. All parametric values are reported at up to three significant figures. Some values are specific to the LEHR site, others are generic. The assumptions for each of these scenarios are as follows:

- Scenario 1 - Continued research use of the site. A hypothetical person is assumed to work in the area of the site.

- Scenario 2 - Recreational use of the site. A hypothetical recreationist is assumed to spend some time during the year at a public park constructed on the remediated area.

- Scenario 3 - Residential use of the site. A hypothetical resident farmer is assumed to live in the remediated area.

IABLE A-1. Parameters Used in the RESRAD Code for Analys is of the LEHR Site

\begin{tabular}{|c|c|c|c|c|}
\hline \multirow[b]{2}{*}{ Parameter } & \multicolumn{4}{|c|}{ Value } \\
\hline & Unit & Scenario 1 & Scenario 2 & Scenario 3 \\
\hline Area of contaminated zone* & $\mathbf{m}^{2}$ & 60.700 & 60,700 & 60,700 \\
\hline Thickness of contaminated zone" & m & 9.1 & 9.1 & 9.1 \\
\hline Length parallel to aquifer flow & m & Not used & 246 & 246 \\
\hline Cover depth* & $\mathbf{m}$ & 0 & 0 & 0 \\
\hline Density of contaminated zone & $\mathrm{g} / \mathrm{cm}^{3}$ & 1.35 & 1.35 & 1.35 \\
\hline Contaminated zone erosion rate ${ }^{b}$ & $\mathrm{~m} / \mathrm{yr}$ & 0.001 & 0.001 & 0.001 \\
\hline Contaminated zone total porosity & - & 0.4 & 0.4 & 0.4 \\
\hline Contaminated zone effective porosity & - & 0.2 & 0.2 & 0.2 \\
\hline Contaminated zone hydraulic conductivity & $\mathrm{m} / \mathrm{yr}$ & 200 & 200 & 200 \\
\hline Contaminated zone b parameter & - & 7.12 & 7.12 & 7.12 \\
\hline Evapotranspiration coefficient ${ }^{b}$ & - & 0.6 & 0.6 & 0.6 \\
\hline Precipitationa & $\mathrm{m} / \mathrm{yr}$ & 0.43 & 0.43 & 0.43 \\
\hline Irrigation & $\mathrm{m} / \mathrm{yr}$ & 0.2 & 0.2 & 0.2 \\
\hline Irrigation mode ${ }^{\mathrm{b}}$ & - & Overhead & Overhead & Overhead \\
\hline Runoff coefficient ${ }^{b}$ & - & 0.4 & 0.4 & 0.4 \\
\hline Watershed area for nearby pond“ & $\mathrm{m}^{2}$ & Not used & $1,000,000$ & $1,000,000$ \\
\hline Density of saturated zone ${ }^{\circ}$ & $\mathrm{g} / \mathrm{cm}$ & Not used & 1.7 & 1.7 \\
\hline
\end{tabular}


IABLE A-1. (contd)

Value

\begin{tabular}{|c|c|c|c|c|}
\hline Parameter & $\underline{\text { Unit }}$ & Scenario 1 & $\underline{\text { Scenario } 2}$ & Scenario 3 \\
\hline Saturated zone total porosity & - & Not used & 0.4 & 0.4 \\
\hline Saturated zone effective porosity ${ }^{\circ}$ & . & Not used & 0.2 & 0.2 \\
\hline Saturated zone hydraulic conductivity ${ }^{*}$ & $\mathbf{m} / \mathbf{y r}$ & Not used & 3,076 & 3,076 \\
\hline Saturated zone hydraulic gradient" & - & Not used & 0.03 & 0.03 \\
\hline Saturated zone b parameter* & - & Not used & 7.75 & 7.75 \\
\hline Water table drop rate ${ }^{b}$ & $\mathrm{~m} / \mathrm{yr}$ & Not used & 0.001 & 0.001 \\
\hline Well pump intake depth (below water table) ${ }^{\mathrm{b}}$ & m & Not used & 10.0 & 10.0 \\
\hline Model: nondispersion (ND) or mass-bal. (MB) & - & Not used & ND model & ND model \\
\hline Number of unsaturated zone strata ${ }^{2}$ & - & Not used & 1 & 1 \\
\hline Unsaturated zone 1 , thickness ${ }^{\mathrm{a}}$ & - & Not used & 13.7 & 13.7 \\
\hline Unsaturated zone 1 , soil density* & $\mathrm{g} / \mathrm{cm}^{3}$ & Not used & 1.35 & 1.35 \\
\hline Unsaturated zone 1 , total porosity* & - & Not used & 0.4 & 0.4 \\
\hline Unsaturated zone 1 , effective porosity & - & Not used & 0.2 & 0.2 \\
\hline Unsaturated zone 1 , soil-specific b parameter ${ }^{\bullet}$ & - & Not used & 7.12 & 7.12 \\
\hline Unsaturated zone 1 , hydraulic conductivity & $\mathrm{m} / \mathrm{yr}$ & Not used & 200 & 200 \\
\hline Inhalation rate ${ }^{b}$ & $\mathrm{~m}^{3} / \mathrm{yr}$ & 8,400 & 8,400 & 8,400 \\
\hline Mass loading for inhalation ${ }^{b}$ & $\mathrm{~g} / \mathrm{m}^{3}$ & 0.0002 & 0.0002 & 0.0002 \\
\hline Shielding factor, inhalation ${ }^{b}$ & - & 0.4 & 0.4 & 0.4 \\
\hline Shielding factor, external gamma ${ }^{b}$ & - & 0.7 & 0.7 & 0.7 \\
\hline Time fraction, indoors & - & 0.057 & 0 & 0.5 \\
\hline Time fraction, outdoors" & - & 0.171 & 0.086 & 0.25 \\
\hline Shape factor, external gamma ${ }^{b}$ & - & 1 & 1 & 1 \\
\hline Dilution length for airborne dust, inhalation ${ }^{b}$ & $\mathbf{m}$ & 3 & 3 & 3 \\
\hline Fruit, vegetable, and grain consumption ${ }^{b}$ & $\mathrm{~kg} / \mathrm{yr}$ & Not used & Not used & 160.0 \\
\hline Leafy vegetable consumption & $\mathrm{kg} / \mathrm{yr}$ & Not used & Not used & 14.0 \\
\hline Milk consumption ${ }^{b}$ & L/yr & Not used & Not used & 92.0 \\
\hline Meat and poultry consumption ${ }^{b}$ & $\mathrm{~kg} / \mathrm{yr}$ & Not used & Not used & 63 \\
\hline Fish consumption ${ }^{b}$ & $\mathrm{~kg} / \mathrm{yr}$ & Not used & 5.4 & 5.4 \\
\hline Other seafood consumption ${ }^{b}$ & $\mathrm{~kg} / \mathrm{yr}$ & Not used & 0.9 & 0.9 \\
\hline Soil ingestion ${ }^{b}$ & $g / y r$ & 36.5 & 36.5 & 36.5 \\
\hline Drinking water intakeb & $\mathrm{L} / \mathrm{yr}$ & Not used & 510 & 510 \\
\hline Fraction of drinking water from site & - & Not used & 0.01 & 1.0 \\
\hline Fraction of aquatic food from site & - & Not used & 0.05 & 0.5 \\
\hline Livestock fodder intake for meat ${ }^{b}$ & $\mathrm{~kg} / \mathrm{d}$ & Not used & Not used & 68.0 \\
\hline Livestock fodder intake for milkb & $\mathrm{kg} / \mathrm{d}$ & Not used & Not used & 55.0 \\
\hline Livestock water intake for meat & $L / d$ & Not used & Not used & 50.0 \\
\hline Livestock water intake for milk & $\mathrm{L} / \mathrm{d}$ & Not used & Not used & 160.0 \\
\hline Mass loading for foliar deposition ${ }^{b}$ & $\mathrm{~g} / \mathrm{m}^{3}$ & Not used & Not used & 0.0001 \\
\hline Depth of soil mixing layerb & $\mathbf{m}$ & 0.15 & 0.15 & 0.15 \\
\hline Depth of roots & $\mathrm{m}$ & Not used & Not used & 0.9 \\
\hline $\begin{array}{l}\text { Groundwater fractional usage (balance } \\
\text { from surface water): }\end{array}$ & & & & \\
\hline Drinking water" & & Not used & 1.0 & 1.0 \\
\hline Livestock water ${ }^{\circ}$ & & Not used & Not used & 1.0 \\
\hline Irrigation" & & Not used & Not used & 1.0 \\
\hline
\end{tabular}


IABLE A-1. (contd)

\begin{tabular}{|c|c|c|c|c|}
\hline \multirow[b]{2}{*}{ Parameter } & \multicolumn{4}{|c|}{ Value } \\
\hline & $\underline{\text { Unit }}$ & Scenario 1 & Scenario 2 & Scenario 3 \\
\hline Total porosity of the cover material ${ }^{\mathrm{t}}$ & - & Not used & Not used & Not used \\
\hline $\begin{array}{l}\text { Total porosity of the house or building } \\
\text { foundation }\end{array}$ & - & Not used & Not used & Not used \\
\hline Volumetric water content of the cover material ${ }^{b}$ & $b$ & Not used & Not used & Not used \\
\hline Volumetric water content of the foundation ${ }^{b}$ & - & Not used & Not used & Not used \\
\hline Diffusion coefficient for radon gas: & $\mathrm{m} / \mathrm{s}$ & & & \\
\hline $\begin{array}{l}\text { In cover material } \\
\text { In foundation material } \\
\text { In contaminated zone soil }\end{array}$ & & $\begin{array}{l}\text { Not used } \\
\text { Not used } \\
\text { Not used }\end{array}$ & $\begin{array}{l}\text { Not used } \\
\text { Not used } \\
\text { Not used }\end{array}$ & $\begin{array}{l}\text { Not used } \\
\text { Not used } \\
\text { Not used }\end{array}$ \\
\hline Emanating power of radon-222 ${ }^{\mathrm{b}}$ & - & Not used & Not used & Not used \\
\hline Emanating power of radon- $220^{\mathrm{b}}$ & - & Not used & Not used & Not used \\
\hline Radon vertical dimension of mixing ${ }^{b}$ & $\mathbf{m}$ & Not used & Not used & Not used \\
\hline Average annual wind speed ${ }^{b}$ & $\mathrm{~m} / \mathrm{s}$ & Not used & Not used & Not used \\
\hline Average building air exchange rate ${ }^{b}$ & $\mathbf{h}^{-1}$ & Not used & Not used & Not used \\
\hline Meight of building (room) ${ }^{\mathrm{b}}$ & m & Not used & Not used & Not used \\
\hline Building indoor area factor & - & Not used & Not used & Not used \\
\hline Bulk density of house or building foundation ${ }^{b}$ & $\mathrm{~g} / \mathrm{cm}^{3}$ & Not used & Not used & Not used \\
\hline Thickness of house or building foundation ${ }^{b}$ & m & Not used & Not used & Not used \\
\hline Building depth below ground surface & $\mathbf{m}$ & Not used & Not used & Not used \\
\hline
\end{tabular}

- Values based on site specifications or scenario assumptions.

- RESRAD default values. 



\section{DISTRIBUTION}

No. of

Copies

OFFSITE

12 Office of Scientific and Technical Information

5 DOE

J. Montella (3)

San Francisco Operations Office 1301 Clay Street

Suite $700 \mathrm{~N}$

0akland, CA

R. Liddle

San Francisco Operations office 1301 Clay Street

Suite $700 \mathrm{~N}$

Oakl and, CA

D.B. Williams

Office of Waste Management

12800 Middlebrook Road

Room 150

Germantown, MD 20874

10 LEHR-University of California

Davis

MSIN ITEH/Battelle

01d Davis Road

Davis, CA 95616

Technica1 Advisory Committee (5)

Steering Committee (5)
No. of

Copies

ONSITE

14 Pacific Northwest Laboratory

S.A. Attiga

T.E. Chapman (5)

J.N. Hartley

D.M. Mitchel]

Publishing Coordination

Technical Report Files (5)

Distr.1 